\title{
Phytoplankton-bacteria interactions: an apparent paradox? Analysis of a model system with both competition and commensalism
}

\author{
G. Bratbak \& T. F. Thingstad \\ Dept. of Microbiology and Plant Physiology, University of Bergen, Allegt 70, 5000 Bergen, Norway
}

\begin{abstract}
Mineral nutrient limitation seems to stimulate phytoplankton excretion of extracellular organic carbon (EOC). Bacterial growth on EOC requires additional uptake of mineral nutrients. A paradoxical situation is thereby created: algae stressed by lack of mineral nutrients respond in a manner whereby they stimulate their competitors for the lacking nutrients. To investigate this paradoxical ecological relation, a simple mathematical model was analysed and compared to a biological model system. The biological model system consisted of the diatom Skeletonema costatum and a strain of a marine bacterium cultured together in chemostats with phosphate as the limiting mineral nutrient. Increasing mineral nutrient limitation by decreasing dilution rate resulted in chemostat equilibria with more bacteria and less algae, confirming the proposed paradox. In a certain sense, algae outcompeted themselves at low dilution rates. Predictions of the simple mathematical model were found to be in agreement both with observed distribution of phosphorus between the 2 populations and with amount of algal carbon biomass in the mixed culture. Implications of results for natural aquatic ecosystems are briefly discussed.
\end{abstract}

\section{INTRODUCTION}

Excretion of organic compounds is considered to be an important part of phytoplankton primary production (Hellebust 1965, 1974, Ignitiades 1973, Storch \& Saunders 1978, Lancelot 1983). Many studies attempting to evaluate bacterial consumption of algal EOC (extracellular organic carbon) in natural waters have been carried out (Derenbach \& Williams 1974, Itturiaga \& Hoppe 1977, Smith et al. 1977. Wiebe \& Smith 1977, Lancelot 1979, Larsson \& Hagström 1979, 1982, Bell \& Sakshaug 1980, Burney et al. 1981, Chróst 1981. Itturiaga 1981, Cole et al. 1982, Wolter 1982, Riemann \& Søndergaard 1984). Such studies have also been carried out in enclosure experiments (Eberlein et al. 1983) and in laboratory systems (Bell et al. 1974, Nalewajko et al. 1976, 1980, Bell 1983, 1984). When excreted compounds are of low mineral nutrient content, bacterial growth will require concomitant uptake of dissolved phosphate and/or nitrogen compounds for synthesis of bacterial biomass. A typical example of such compounds would be carbohydrates which seem to be a common algal excretory product (Myklestad 1974).

In an environment where primary production is limited by the availability of mineral nutrients, this would lead to competition between phytoplankton and heterotrophic bacteria for the limiting mineral nutrient. The scant experimental evidence on the subject of bacterial/algal competition seems to suggest that bacteria are more efficient competitors for mineral nutrients than algae (Rhee 1972, Parker et al. 1975, Parsons et al. 1981, Currie \& Kalff 1984a, b). From a theoretical point of view, this could be expected, considering the larger surface to volume ratio of the small bacteria. Experimental evidence of such a relation between small size and competitive advantage in nutrent uptake was found by Smith \& Kalff (1982) for phytoplankton. In chemostat competition experiments with bacteria, Kuenen et al. (1977) found species with large surface/volume ratios to dominate at low dilution rates. Several investigations (Ignitiades \& Fogg 1973, Myklestad 1977, Joiris et al 1982, Lancelot 1983, 1984) suggest that excretion may be favoured when mineral nutrient supplies become exhausted. If this is a general feature, a somewhat paradoxical situation emerges: phytoplankton stressed by the lack of mineral nutrients respond in a manner whereby they apparently stimulate their competitors.

If we try to resolve this paradox by assuming bacteria 
to have an equal or inferior ability to compete with phytoplankton for mineral nutrients, bacteria and algae would be limited by the same nutrient, and we end up instead with a modification of the classical paradox of plankton (Hutchinson 1961): why so so many different species coexist on the same limiting nutrient in such a (seemingly?) homogenous environment. Now, however, this paradox embraces bacteria in addition to phytoplankton. In situations with large inputs of allochthonous organic material, algal-bacterial mineral nutrient competition would be expected to have a 2-sided effect: bacterial degradation of organic material would be negatively affected by primary producers, and/or primary production would be negatively influenced by bacterial activity. This has been been investigated in some field studies (Parker et. al 1975, Parsons et al. 1981) and theoretical considerations (Thingstad \& Pengerud 1985). In such situations, where organic material is added, limitation of bacterial growth due to lack of carbon and energy may be released. The possibility then exists that competition for mineral nutrients is the main ecological interaction between phytoplankton and bacteria. In a situation were organic material excreted from phytoplankton is the main carbon/energy source for bacterial growth, a combination of competition and commensalism may be expected. The effect of a competition/commensal relation on the biomass distribution between algae and bacteria is not obvious. Bacteria cannot outcompete the algae completely since this would remove their source of carbon/energy substrate. With their assumed superiority in mineral nutrient competition, the bacterial population should increase as long as dissolved organic substrates are available. We have made an attempt to explore the properties of the algae/bacteria/ EOC/mineral-nutrient system by analysing the behavior of a simple mathematical model for chemostat growth, and have compared this to an experimental model system.

\section{MATHEMATICAL MODEL}

Based more on its attractive simplicity than on direct experimental evidence, we have applied the following conceptual model of algal EOC-production: phytoplankton limited by mineral nutrients can only use a part of their photosynthetic capacity for production of new biomass. The remaining capacity may either be 'shut off', or the surplus organic material produced may be excreted. We have assumed a constant fraction of the remaining capacity to be functioning, producing extracellular organic carbon compounds. Mathematically, this may be formulated as:

$$
\mathrm{e}=\alpha_{1}\left(\mu_{\mathrm{A}}^{\max }-\mu_{\mathrm{A}}\right)
$$

where e $=$ excretion rate of organic material per algal unit; $\alpha_{1}=$ a constant with dimension units of organic material per algal unit; $\mu_{A}^{\max }=$ specific algal growth rate attained when growth is not mineral nutrient limited; $\mu_{A}=$ specific growth rate attained under the actual, nutrient limited, conditions (symbols are sum-

Table 1. Symbols used

\begin{tabular}{|c|c|c|}
\hline Symbol & Explanation & Uni \\
\hline$A_{p}$ & Phosphorus content of algal biomass & $\mu g$-at $P l^{-1}$ \\
\hline$A_{C}$ & Carbon content of algal biomass when grown alone & $\mu g$-at $\mathrm{C} \mathrm{I}^{-1}$ \\
\hline$B_{P}$ & Phosphorus content of bacterial biomass & $\mu g$-at $\mathrm{Pl}^{-1}$ \\
\hline $\mathrm{B}_{\mathrm{C}}$ & Carbon content of bacterial biomass & $\mu \mathrm{g}-\mathrm{at} \mathrm{Cl^{-1 }}$ \\
\hline $\mathrm{C}$ & Concentration of EOC in culture & $\mu \mathrm{g}$-at $\mathrm{Cl}^{-1}$ \\
\hline $\mathrm{P}$ & Concentration of dissolved phosphate in culture & $\mu g$-at $P^{-1}$ \\
\hline$P_{1}$ & Concentration of dissolved phosphate in reservoir & $\mu g$-at $\mathrm{P}^{-1}$ \\
\hline e & Specific algal excretion rate & $\mu g$-at $C(\mu g \text {-at } P)^{-1}$ \\
\hline$\mu_{A}^{\max }$ & Maximum specific algal growth rate & $\mathrm{h}^{-1}$ \\
\hline$\mu_{\mathrm{A}}$ & Specific algal growth rate & $h^{-1}$ \\
\hline $\mathrm{r}_{\mathrm{A}}$ & Molar $\mathrm{C}: \mathrm{P}$ ratio of algal biomass & $\mu g$-at $C(\mu g \text {-at } P)^{-1}$ \\
\hline$r_{A}^{\circ}$ & Molar $\mathrm{C}: \mathrm{P}$ ratio of algal biomass when growth is not nutrient limited & $\mu g-a t C(\mu g \text {-at } P)^{-1}$ \\
\hline$\hat{\mu_{\mathrm{B}}}$ & Specific bacterial growth rate & $\mathrm{h}^{-1}$ \\
\hline$Y_{B C}$ & Bacterial yield on EOC & $\mu g$-at $P(\mu g \text {-at } C)^{-1}$ \\
\hline$a_{1}$ & Excretion rate proportionality factor (see Eq. [1] in text) & $\mu g-a t C(\mu g-a t P)^{-1}$ \\
\hline$\alpha_{2}$ & Constant describing variation of algal C: $P$ ratio (see Eq. [6] in text) & dimensionless \\
\hline $\mathrm{D}$ & Dilution rate & $\mathrm{h}^{-1}$ \\
\hline$D^{\prime}$ & $=\mathrm{D} / \mu_{\mathrm{A}}^{\max }$ & dimensionless \\
\hline$\alpha_{1}^{\prime}$ & $=\alpha_{1} Y_{B C}$ & dimensionless \\
\hline
\end{tabular}


marized in Table 1). This expression may be incorporated into a set of traditional chemostat equations (Table 2) describing 2 species, bacteria and algae, and 2 potentially limiting nutrients, EOC (C), and a mineral nutrient (P). To simplify the discussion we assume

Table 2. Differential equations describing chemostat growth of bacteria and algae with phosphate as the limiting mineral nutrient

$$
\begin{aligned}
& \frac{d A_{P}}{d t}=\left(\mu_{A}-D\right) A_{P} \\
& \frac{d B_{P}}{d t}=\left(\mu_{B}-D\right) B_{P} \\
& \frac{d C}{d t}=-C D+e A_{P}-Y_{B P}^{-1} \mu_{B} B_{P} \\
& \frac{d P}{d t}=\left(P_{3}-P\right) D-\mu_{A} A_{P}-\mu_{B} B_{P}
\end{aligned}
$$

Comments:

- There is no term in Eq. (2.3) for input of $C$ from reservoir since the only carbon source for bacterial growth is assumed to be supplied by algal excretion

- The term eA in Eq. (2.3) represents algal production of C, e is defined by Eq. (1) in the text

- There are no 'yield coefficients' in in the 2 last terms of Eq. (2.4) since A and B are given in terms of phosphorus biomass

the limiting mineral nutrient to be phosphorus, which we used in our experiments. The equations are formulated in terms of algal and bacterial phosphorus biomass $\left(A_{p}\right.$ and $B_{p}$, respectively). The coexistence of algae and bacteria may be analysed along the same lines of reasoning as used by Thingstad \& Pengerud (1985). Assuming $\mu_{A}$ to be a function of $P$ only, while both $\mathrm{P}$ and $\mathrm{C}$ are required for bacterial growth, $\mathrm{a}$ necessary requirement for stable coexistence is that the line $\mu_{\mathrm{A}}(\mathrm{P})=\mathrm{D}$ and the curve $\mu_{\mathrm{B}}(\mathrm{C}, \mathrm{P})=\mathrm{D}$ intersect (Fig. 1). At this intersection, both populations grow at a rate equal to the dilution rate. If the alga has a high affinity for phosphate and/or a high maximum growth rate relative to the bacteria, the line and the curve may not intersect, no coexistence equilibrium is then possible and the bacteria will be outcompeted.

If a coexistence equilibrium exists, the equilibrium values for algal $\left(A_{P}^{A B}\right)$ and bacterial $B_{P}^{A B}$ phosphorus content may be solved using Eq. (1) and Eq. (2.1) to (2.4) (Table 2) with all differentials equal to zero. With the additional assumption that equilibrium concentrations in the culture of EOC and phosphate are negligible, some rearrangement gives:

$$
A_{P}^{A B} / P_{i}=\frac{1}{1+\alpha Y_{B C}\left(\frac{\mu_{A}^{\max }}{D}-1\right)}
$$

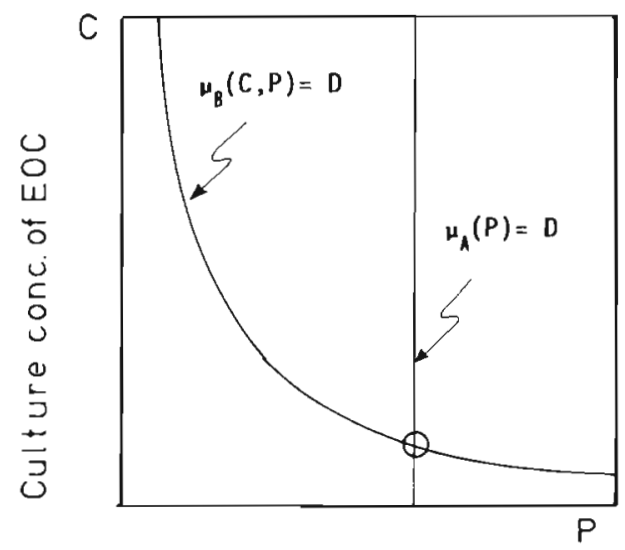

Culture conc of mineral nut.

Fig. 1. A necessary requirement for coexistence of bacteria and alga is that a value of $C$ and $P$ exist for which both bacterial and algal specific growth rates equal the dilution rate. If the concentration of mineral nutrient at which $\mu_{\mathrm{A}}=\mathrm{D}$ is too low for bacteria to attain $\mu_{B}=D$, bacteria will be outcompeted

$$
\mathrm{B}_{\mathrm{P}}^{\mathrm{AB}} / \mathrm{P}_{\mathrm{i}}=\frac{\alpha \mathrm{Y}_{\mathrm{BC}}\left(\frac{\mu_{\mathrm{A}}^{\max }}{\mathrm{D}}-1\right)}{1+\alpha \mathrm{Y}_{\mathrm{BC}}\left(\frac{\mu_{\mathrm{A}}^{\max }}{\mathrm{D}}-1\right)}
$$

These equations may be considered as functions of one dimensionless variable:

$$
\mathrm{D}^{\prime}=\mathrm{D} / \mu_{\mathrm{A}}^{\max }
$$

and one dimensionless parameter only:

$$
\alpha_{1}^{\prime}=\alpha_{1} Y_{\mathrm{BC}}
$$

The theoretical variation in the fraction of added phosporus retained in algal biomass with varying $D^{\prime}$ is shown in Fig. 2 for different values of $\alpha_{1}^{\prime}$. In the extreme

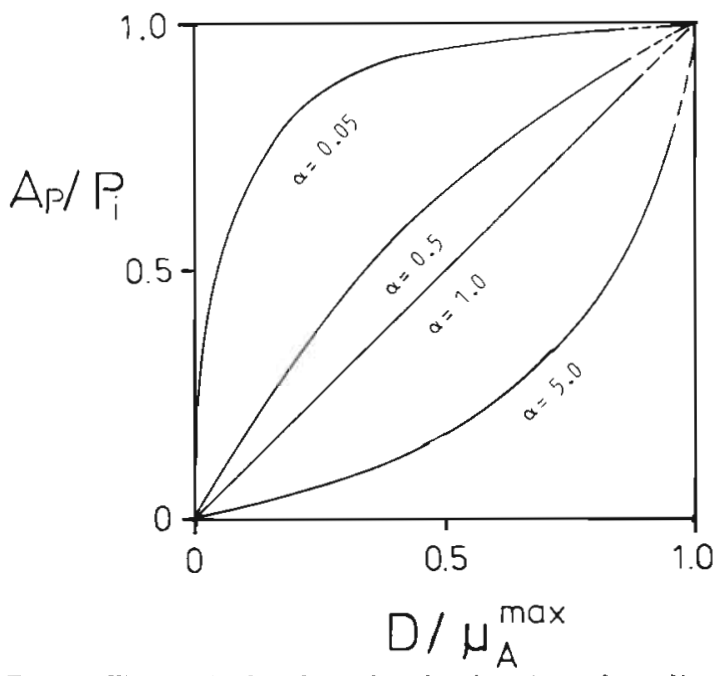

Fig. 2. Theoretical values for the fraction of medium phosphate $\mathrm{P}_{1}$ incorporated into algal biomass at different dilution rates. Curves are given for different values of the dimensionless parameter $\alpha_{1}^{\prime}$ 
case of small algal excretion (small $\alpha_{1}$ ) and a small amount of phosphorus incorporated into bacterial biomass per unit EOC consumed (small $\mathrm{Y}_{\mathrm{BC}}$ ), the mixed culture will be dominated by algae except when $D^{\prime}$ approaches zero. In the opposite case with the product $\alpha_{1} Y_{B C}$ much larger than 1 , the culture will be dominated by bacteria except for $D^{\prime}$ approaching $\mu_{A}^{\max }$. (At $\mathrm{D}^{\prime}$ close to $1, \mathrm{C}$ and $\mathrm{P}$ will not be negligible, and Eq. (3.1) and (3.2) are no longer valid).

So far, this model does not relate to the carbon content of algae. We have fitted an empirical formula to the curve in Fig. 4, describing variation in algal carbon biomass with dilution rate. Algal biomass carbon may be expressed as:

$$
A_{C}=r_{A} A_{P}
$$

where $\mathrm{r}_{\mathrm{A}}=$ molar $\mathrm{C}:$ P ratio of the algae at the specific growth rate $\mu_{A}$. A reasonable fit to our data was found using the expression:

$$
r_{A}=r_{A}^{o}\left(1+\alpha_{2}\left[\frac{\mu_{A}^{\max }}{D}-1\right]\right)
$$

where $\mathrm{r}_{\AA}^{\circ}=\operatorname{algal} \mathrm{C}: \mathrm{P}$ ratio when growth is unrestricted with respect to mineral nutrient availability; $\alpha_{2}=a$ dimensionless proportionality constant. It should be noted, however, that this would not be a satisfactory model at extremely low values of $D$ since $r_{A}$ increases infinitely as $D$ approaches zero.

At chemostat equilibrium $\mu_{\mathrm{A}}=\mathrm{D}$ and we get the 2 following equations for algal carbon biomass. In the 'algae alone' chemostat:

$$
\mathrm{A}_{\mathrm{C}}^{\mathrm{A}} / \mathrm{P}_{\mathrm{j}}=\mathrm{r}_{\mathrm{A}}^{\circ}\left(1+\alpha_{2}\left[\frac{\mu_{\mathrm{A}}^{\max }}{\mathrm{D}}-1\right]\right)
$$

and in the 'algae and bacteria' chemostat:

$$
\begin{aligned}
A_{C}^{A B} / P_{i}=r_{A}^{\circ}\left(1+\alpha_{2}\left[\frac{\mu_{A}^{\max }}{D}-1\right]\right) \\
\quad\left(1+\alpha_{1} Y_{B C}\left[\frac{\mu_{A}^{\max }}{D}-1\right]\right)^{-1}
\end{aligned}
$$

In the mixed culture, culture concentration of algal carbon biomass would, according to Eq. (7.2), be independent of, increase, or decrease with $\mathrm{D}^{\prime}$, dependent upon whether the ratio of $\alpha_{2}$ to $\alpha_{1}^{\prime}$ is equal to, less than, or greater than 1.

\section{MATERIALS AND METHODS}

Continuous culture system. Three chemostats were run simultaneously under identical conditions: 'algae alone', 'algae and bacteria'; and 'bacteria alone'. The diatom Skeletonema costatum and an unidentified vibrio-shaped marine bacterium denoted $\mathrm{CH} 1$ were used. Continuous lighting, $26 \mathrm{Wm}^{-2}$ at the surface of the cultures, was provided by fluorescent tubes. The temperature was kept at $15^{\circ} \mathrm{C}$. The cultures were aerated with humidified and sterile filtered air at a rate of 300 $\mathrm{ml} \mathrm{min}^{-1}$. The medium was prepared from aged seawater diluted to $70 \%$ distilled water. To remove larger debris, the medium was prefiltered through a coarse cellulose filter. After autoclaving, the medium was enriched with $\mathrm{NaNO}_{3}(100 \mu \mathrm{M}), \mathrm{Na}_{2} \mathrm{SiO}_{3}(20 \mu \mathrm{M})$, trace elements and vitamins (Eppley et al. 1967). Phosphate concentration of the medium was adjusted to a final concentration of $1 \mu \mathrm{M}$ by adding appropriate amounts of a $1 \mathrm{mM}$ solution of $\mathrm{KH}_{2} \mathrm{PO}_{4}$.

At each dilution rate, the chemostats were run until steady state was reached, i.e. until no further change in population density of algae and bacteria was observed with time. Before each harvesting, the pure culture of Skeletonema costatum was checked for bacterial contamination. Both examination of acridine orange stained preparates and plating on agar nutrient plates confirmed that the cultures were uncontaminated.

By mapping the sensitivity of $\mathrm{CH} 1$ against 12 different antibiotics (Oxoid antibiotica discs) we were able to recognize it unequivocally. This antibiotic sensitivity mapping was performed routinely before each harvesting of cultures and we always concluded that the bacterium growing in the cultures was $\mathrm{CH} 1$ and not an unidentified contaminant.

Biomass and chemical analysis. Algae were counted in a nanoplankton counting slide using a phase contrast microscope. Bacteria were stained with acridine orange and counted using an epifluorescence microscope (Hobbie et al. 1977). Biovolumes of bacterial cells were obtained by measuring the length and width of the cells on scanning electron microscope (SEM) photographs, and by measuring the size of acridine orange stained cells using an eyepiece graticule (Bratbak 1985). Biovolume of bacteria was converted into

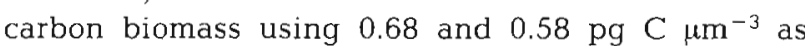
conversion factors for the volumes obtained with SEM and epifluorescence microscopy, respectively (Bratbak 1985). Estimates of bacterial carbon biomass obtained by the 2 methods were found to be comparable.

Total particulate organic carbon (POC) in the cultures was determined by filtering 10 to $50 \mathrm{ml}$ of culture onto precombusted glassfibre filters (Whatman GF/F) and analysing in a CHN-analyser (Carlo Erba Instrumentazione 1106). As our medium was made using natural seawater, particulate organic debris gave a background in our carbon analysis. This background was estimated as the difference between POC and bacterial carbon in the culture where $\mathrm{CH} 1$ was grown alone. The background was assumed to be the same in all 3 cultures. Carbon biomass of the algal cells in the mixed culture was estimated as the difference between POC and bacterial carbon. 
Phosphorus content in algae and bacteria was measured by filtering $40 \mathrm{ml}$ of the cultures onto $1 \mu \mathrm{m}$ and $0.2 \mu \mathrm{m}$ pore size Uni-Pore filters in sequence. The filters were transferred to glass ampoules combusted at $500{ }^{\circ} \mathrm{C}$, and analysed for total phosphorus according to Koroleff (1976). Phosphorus content of algae and of bacteria in the 2 pure cultures was estimated as the sum of particulated phosphorus remaining on the $1 \mu \mathrm{m}$ and $0.2 \mu \mathrm{m}$ pore size filters. Assuming the same separation efficiency for alga and for bacteria by the $1 \mu \mathrm{m}$ filter in the mixed culture, as could be calculated for the 2 pure cultures, we could estimate the phosphorus content of algae and bacteria in the mixed culture (Method 1). Phosphorus content of the 2 populations in the mixed culture was also estimated assuming algae in the mixed culture to have the same phosphorus cell quota (same C:P ratio) as algae in the pure culture (Method 2). This assumption is justified using the theory for algal growth developed by Droop (1968) which states that there is a direct relation between phosphorus cell quota and growth rate. At steady state, algal growth rate equals dilution rate whether the algae grows alone or in a mixed culture. Phosphorus content of bacteria in the mixed culture was estimated as the difference between total particulate phorphorus and algal phosphorus.

\section{RESULTS}

To fit the equations for phosphorus biomass (Eq. [3.1] $\&[3.2])$ to the observed data, 1 parameter, $\alpha_{1}^{\prime}$, has to be estimated. The value of $D^{\prime}$ (denoted $D_{1 / 2}^{\prime}$ ) for which phosphorus is evenly distributed between algae and bacteria may be estimated from the data points in Fig. 3. This gives an approximate value of $D_{1 / 2}^{\prime}=0.07$.

The relation between $D_{1 / 2}^{\prime}$ and $\alpha_{1}^{\prime}$ is given as (rearranging Eq. [3.1]):

$$
\alpha_{1}^{\prime}=\frac{D_{1 / 2}^{\prime}}{1-D_{1 / 2}^{\prime}}
$$

Insertion of $D_{1 / 2}^{\prime}=0.07$ gives $\alpha_{1}^{\prime}=0.08$. The theoretical curves (Eq. [3.1] \& [3.2]) corresponding to this value of $\alpha_{1}^{\prime}$ are drawn in Fig. 3. The values of $r_{A}^{o}$ and $\alpha_{2}$ may be estimated by fitting Eq. (7.1) to the data for carbon content in algal biomass in Fig. 3. The theoretical curve for $r_{\AA}^{\circ}=116 \mu \mathrm{g}$-at $\mathrm{C}(\mu \mathrm{g} \text {-at } \mathrm{P})^{-1}$ and $\alpha_{2}=0.10$ is shown in Fig. 4.

All the parameters determining algal carbon content in the situation with algae and bacteria together are then given and the theoretical curve based on Eq. (7.2) is drawn in Fig. 4. The corresponding experimental data are also shown.

With the volume to carbon conversion factor proposed by Bratbak (1985) the mean bacterial C:P ratio

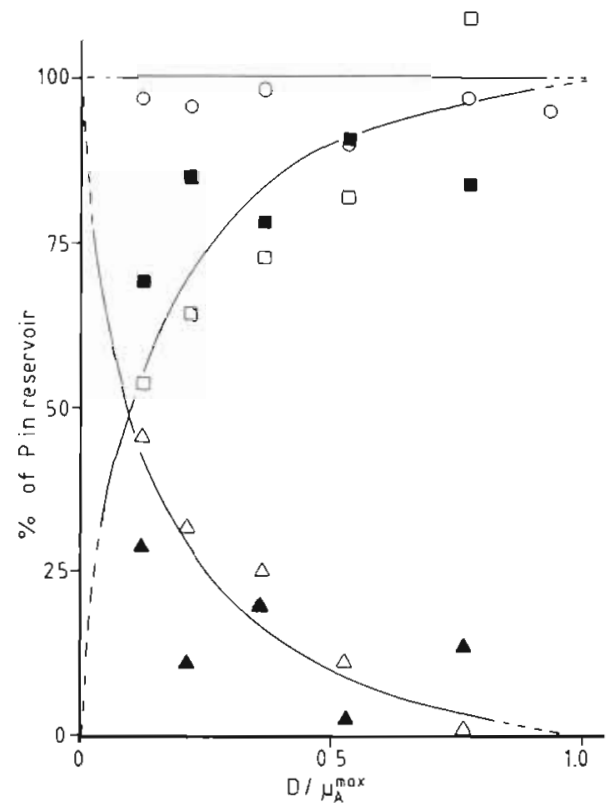

Fig. 3. Observed values for equilibrium distribution of medium phosphate into algal biomass in 'algae alone' $(O)$ and into algae $(\square, \boldsymbol{\square})$ and bacteria $(\Delta, \mathbf{\Delta})$ in 'algae and bacteria' chemostats as functions of dilution rate. Filled symbols represent values obtained by Method 1 and open symbols by Method 2 (see 'Materials and Methods'). Lines correspond to theoretical model (Eq. [3.1] \& [3.2] with $\alpha_{1}^{\prime}=0.08$ )

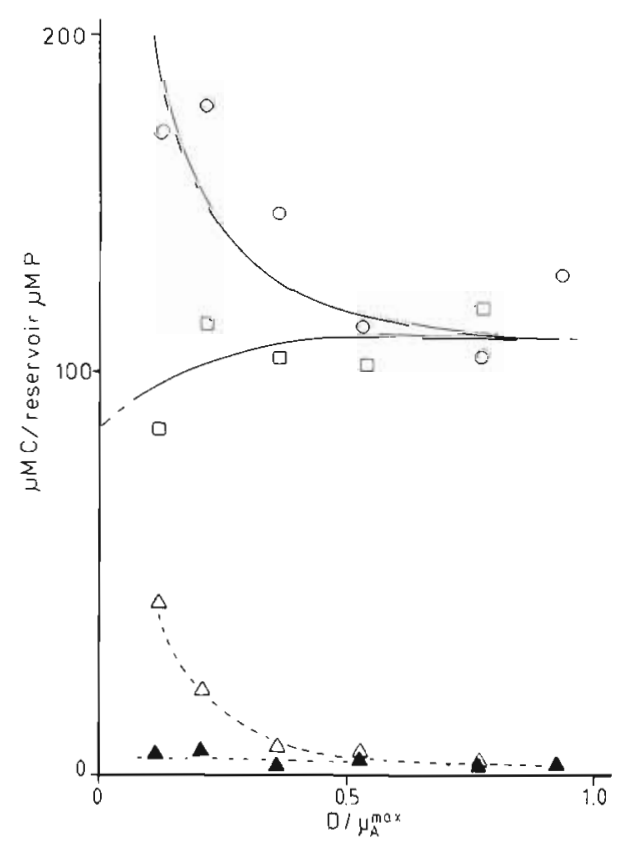

Fig. 4. Observed values for carbon in algae in 'algae alone' (O) and 'algae and bacteria' ( $\square$ ) chemostats, and carbon in bacteria in 'bacteria alone' $(\mathbf{A})$ and 'algae and bacteria' $(\Delta)$ chemostats. Solid lines represent Eq. (7.1) and (7.2) with $\alpha_{2}=$ 0.10 . Bacterial biomass carbon (dotted lines) is not included in the theoretical framework 
(molar) in the mixed culture was found to be 109 (range 28 to 218 ). Assuming $50 \%$ assimilation efficiency, this gives an estimated mean $Y_{B C}$ of $0.005 \mu \mathrm{g}$-at $\mathrm{P}$ ( $\mu \mathrm{g}$-at $C)^{-1}$. Since $\alpha_{1}^{\prime}=\alpha_{1} Y_{B C}$ was estimated to 0.08 , this gives an estimated value of $\alpha_{1}$ of $16 \mu \mathrm{g}$-at $C$ ( $\mu \mathrm{g}$-at $\left.\mathrm{P}\right)^{-1}$.

The production of EOC as percent of total primary production may be estimated assuming that all EOC has been converted into bacterial biomass with assimilation efficiency $50 \%$. Percent extracellular release (PER) was found to range from $6 \%$ at high dilution rate, to $50 \%$ at low dilution rate (Table 3 ).

Table 3. Estimates of per cent extracellular release (PER) based on an assumed assimiliation efficiency of $50 \%$ in bacteria

\begin{tabular}{|cc|}
\hline$D^{\prime}$ & $P E R=\frac{2 B_{C}}{A_{C}+2 B_{C}} 100 \%$ \\
\hline 0.12 & 50 \\
0.21 & 28 \\
0.36 & 12 \\
0.53 & 11 \\
0.77 & 6 \\
\hline
\end{tabular}

Carbon content in bacteria in the 'bacteria alone' chemostat is shown in Fig. 4. This bacterial population reflects the level of degradable organic material in our seawater-based medium.

\section{DISCUSSION}

In a recent publication, Currie \& Kalff (1984b) describe experiments with algae and bacteria cultured together in a chemostat system. Their main result was identical to ours: an equilibrium was established with bacteria and algae coexisting. Our mathematical analysis demonstrates how the effect of increasing mineral nutrient limitation, by decreasing dilution rate in a chemostat system, could shift the equilibrium towards bacterial dominance, i.e. towards a system were algae initiate their own reduction by stimulating their competitors.

The distribution of phosphorus between algae and bacteria predicted by our crude model fits reasonably with the observed data (Fig. 3). This is encouraging since 1 parameter only is involved. There is also a reasonable fit between the theoretical curve and data for algal carbon biomass in the 'algae and bacteria' chemostat (Fig. 4). In this case, all the parameters necessary to produce the theoretical curve were obtained from previous fittings between theroy and data. This should, however, not be taken as a proof of the proposed model. There is obvious scatter in the data, and alternative models possibly producing equal or similar patterns have not been explored.

One such alternative mechanism could be increased death rate of algal cells at low dilution rates. Bacterial growth could then presumably proceed on carbon and phosphorus from the dead algae. If this was true, the competition for phosphorus would disappear or at least be diminished. Doubts have been raised as to the importance of EOC excretion as a process in normal, undisturbed phytoplankton (Sharp 1977, 1984), and it is difficult to reject entirely the hypothesis of bacterial growth on dead algal cells. Several observations are, however, inconsistent with this way of interpreting the data: in the 'algae alone' chemostat, our phosphorus budget based on measurement of particulate phosphonus is in balance (Fig. 3). This shows that the algae had not become leaky, Combined with the observation that orthophosphate is rapidly released from dead algal material by autolysis (Garber 1984), this suggests that only a minor fraction of the algae in our experiment could be dead. Bacterial growth on material retained in dead algae would be expected to be revealed by bacteria attached to the algae. Attached bacteria as well as empty frustules were only rarely observed. Our estimates of PER (Table 3) are in agreement with estimates of PER by Ignitiades \& Fogg (1973) using nutrient-limited Skeletonema costatum cultures. However, if we assume that bacterial production was supported by organic carbon from dead algal cells only, and not from production of EOC as proposed, the values given for PER could in principle be interpreted as the percentage of dead algal cells in the cultures.

If our interpretation of the interaction between algae and bacteria as a competition/commensal-relation is correct, both Currie \& Kalff's (1984b) and our results demonstrate that bacteria may be better competitors for orthophosphate than algae. Care should be taken in generalizing this result to natural systems. Model systems may also be constructed with phytoplankton species outcompeting bacteria in chemostats (Thingstad unpubl.). It is also known that competitive advantage in a variable environment may depend upon other physiological properties than advantage in a continuous flow chemostat (Sommer 1984). One of the important environmental fluctuations not included in our theoretical and laboratory models is diurnal light variation. If, on the other hand, bacteria are generally inferior competitors to phytoplankton, some explanation must be provided as to the mineral nutrient source sustaining what seems to be a rapid bacterial turnover of algal exudates in some environments (Wiebe \& Smith 1977; Lancelot 1979). According to this line of reasoning, bacteria in aquatic systems would be carbon limited rather than mineraI nutrient limited. The 
consequences of more complex ecological interactions such as predator control of the bacterial population (Fenchel 1982), are not taken into consideration here.

Our experimental and theoretical results would suggest that a large percentage of primary production in natural systems could be diverted through the 'microbial loop' (Azam et al. 1983) and that a shift towards a greater heterotroph/autotroph biomass ratio could be expected in severely nutrient-limited pelagic ecosystems.

The model proposed here for phytoplankton excretion of organic compounds under conditions where nutrient supply is limiting, but mineral carbon and light are available in excess, seems physiologically reasonable. The apparent paradox of algal stimulation of their own competitors seem to occur when 1 other trophic level is included: the bacteria. One could attempt to resolve this paradox by including higher trophic levels such as bacterial predators, providing nutrient regeneration. It is, however, not immediately clear how this could be of advantage to the phytoplankton since the bacteria and the predator chain would necessarily tie up mineral nutrients in their biomass.

Acknowledgements. This work was partly financed by the Norwegian Program for Marine Arctic Ecology (PRO MARE). The authors thank colleagues at the Department of Microbiology and Plant Physiology, University of Bergen for critical reading of the manuscript.

\section{LITERATURE CITED}

Azam, F., Fenchel, T., Field, J. G., Gray, J. S., Meyer-Reil, L. A., Thingstad, F. (1983). The ecological role of watercolumn microbes in the sea. Mar. Ecol. Prog. Ser. 10: $257-263$

Bell, W. H. (1983). Bacterial utilization of algal extracellular products 3 . The specificity of algal-bacterial interactions. Limnol. Oceanogr 28: 1131-1143.

Bell, W. H. (1984). Bacterial adaption to low nutrient conditions as studied with algal extracellular products. Microb. Ecol. 10: 217-230

Bell, W. H., Lang, J. M., Mitchell, R. (1974). Selective stimulation of marine bacteria by algal extracellular products. Limnol. Oceanogr. 19: 833-839

Bell, W. H., Sakshaug, E. (1980). Bacterial utilization of algal extracellular products 2. A kinetic study of natural populations. Limnol. Oceanogr. 25: 1021-1033

Bratbak, G. (1985). Bacterial biovolume and biomass estimations. Appl. environ. Microbiol. 49: 1488-1493

Burney, C. M., Johnson, K. M., Lavoie, D. M., Sieburth, J. McN. (1981). Dependence of dissolved carbohydrate concentrations upon small scale nanoplankton and bacterioplankton distributions in the western Saragasso Sea. Mar. Biol 65: 289-296

Chróst, R. J. (1981). The composition and bacterial utilization of DOC released by phytoplankton. Kieler Meeresforsch. (Sonderh.) 5: 325-332

Currie, D. J., Kalff, J. (1984a). A comparison of the abilities of freshwater algae and bacteria to acquire and retain phosphorus. Limnol. Oceanogr, 29: 298-310

Currie, D. J., Kalff, J. (1984b). Can bacteria outcompete phytoplankton for phosphonus? A chemostat test. Microb. Ecol. 10: 205-216

Cole, J. J., Likens, G. E., Strayer, D. L. (1982) Photosynthetically produced dissolved organic carbon: An important carbon source for planktonic bacteria. Limnol. Oceanogr. 27: $1080-1090$

Derenbach, J. B., Williams, P. J. (1974). Autotrophic and bacterial production: fractionation of plankton samples from the English Channel. Mar. Biol. 25: 263-269

Droop, M. R. (1968) Vitamin $B_{12}$ and marine ecology. IV. The kinetics of uptake, growth and inhibition in Monochrysis lutheri. J. mar. biol. Ass. U. K. 48: 689-733

Eberlein, K., Brockmann, U. D., Hammer, K. D., Kattner, G., Laake, M. (1983). Total dissolved carbohydrates in an enclosure experiment with unialgal Skeletonema costatum culture. Mar. Ecol. Prog. Ser. 14: 45-58

Eppley, R. W., Holmes, R. W., Strickland, J. D. H. (1967) Sinking rates of marine phytoplankton measured with a fluorometer. J. exp. mar. Biol. Ecol. 1: 191-208

Fenchel, T. (1982). Ecology of heterotrophic microflagellates. IV. Quantitative occurrence and importance as bacterial consumers. Mar. Ecol. Prog. Ser. 9; 35-42

Garber, J. H. (1984). Laboratory study of nitrogen and phosphorus remineralization during the decomposition of coastal plankton and seston. Estuar. coast. Shelf Sci. 18: $685-702$

Hellebust, J. A. (1965). Excretion of some organic compounds by marine phytoplankton. Limnol. Oceanogr. 10: 192-206

Hellebust, J. A. (1974). Extracellular products. Bot. Monogr. 10: 838-863

Hutchinson, G. E. (1961). The paradox of the plankton. Am. Nat. 95: 137-145

Hobbie, J. E., Daley, R. J., Jasper, S. (1977). Use of Nucleopore filters for counting bacteria by fluorescence microscopy. Appl. environ. Microbiol. 33: 1225-1228

Ignitiades, L. (1973). Studies on the factors affecting the release of organic matter by Skeletonema costatum (Greville) Cleve in field conditions. J. mar. biol. Ass. U. K. 53: 923-935

Ignitiades, L., Fogg, G. E. (1973). Studies on the factors affecting the release of organic matter by Skeletonema costatum (Greville) Cleve in culture. J. mar. biol. Ass. U. K. 53: $937-956$

Itturiaga, R. (1981). Phytoplankton photoassimilated extracellular products; heterotrophic utilization in marine environment. Kieler Meeresforsch. (Sonderh.) 5: 318-324

Itturiaga, R., Hoppe, H. G. (1977). Observations on heterotrophic activities on photoassimilated organic matter. Mar. Biol. 40: 101-108

Joiris, C., Billen, G., Lancelot, D., Daro, M. H., Mommaerts, J. P., Bertels, A., Bossicart, M., Nijs, J., Hecq, J. H. (1982). A budget of carbon cycling in the Belgian coastal zone Relative roles of zooplankton, bacteriplankton and benthos in the utilization of primary production. Neth. J. Sea. Res. 16: 260-275

Koroleff, F. (1976). Determination of phosphorus. In: Grasshoff, K. (ed.) Methods of seawater analysis. Verlag Chemie, Weinheim, New York

Kuenen, J. G., Boonstra, J., Scröder, H. G. J., Veldkamp, H. (1977) Competition for inorganic substrates among chemoorganotrophic and chemolithtrophic bacteria. Microb. Ecol. 3: 119-130

Lancelot, C. (1979). Gross excretion rates of natural marine phytoplankton and heterotrophic uptake of excreted pro- 
ducts in the southern North Sea, as determined by short term kinetics. Mar Ecol. Prog. Ser. 1: 179-186

Lancelot, C. (1983). Factors affecting phytoplankton extracellular release in the Southern Bight of the North Sea. Mar Ecol. Prog. Ser 12: 115-121

Lancelot, E. (1984). Metabolic changes in Phaeocystis poucheti (Hariot) Lagerheim during the spring bloom in Belgian coastal waters. Estuar. coast. Shelf Sci. 18: $593-600$

Larsson, U., Hagström, A. (1979). Phytoplankton exudate release as energy source for the growth of pelagic bacteria. Mar. Biol. 52: 199-206

Larsson, U., Hagström, A. (1982). Fractionated phytoplankton primary production, exudate release and bacterial production in a Baltic eutrophication gradient. Mar. Biol. 67: $57-70$

Myklestad, S. (1974). Production of carbohydrates by marine planktonic diatoms. I. Comparison of nine different species in culture. J. exp. mar. Biol. Ecol. 15: 261-274

Myklestad, S. (1977). Production of carbohydrates by marine planktonic diatoms. II. Influence of the N/P ratio in the growth medium on the assimilation ratio, growth rate, and production of cellular and extracellular carbohydrates by Chaetocheros affinis var. Willei (Gran) Hustedt and Skeletonema costatum (Grev.) Cleve. J. exp. mar. Biol. Ecol. 29: 161-179

Nalewajko, C., Dunstall, T. G., Shear, H. (1976). Kinetics of extracelluiar release in axenic algae and in mixed algalbacterial cultures: significance in estimation of total (gross) phytoplankton excretion rates. J. Phycol. 12: 1-5

Nalewajko, C., Lee, K., Fay, P. (1980). Significance of algal extracellular products to bacteria in lakes and in cultures. Microb. Ecol. 6: 199-207

Parsons, T. R., Albright, L. J., Whitney, F., Wong, C. S., Williams, P. J. (1981). The effect of glucose on the productivity of seawater: An experimental approach using controlled aquatic ecosystems. Mar. environ. Res. 4: 229-242

Parker, R. R., Sibert, J., Brown, T. J. (1975). Inhibition of primary productivity through heterotrophic competition for nitrate in a stratified estuary. J. Fish. Res. Bd Can. 32: $72-77$

Rhee, G-Yull (1972). Competition between an alga and an aquatic bacterium for phosphate. Limnol. Oceanogr 17 505-514

Riemann, B., Sondergaard, M. (1984). Bacterial growth in relation to phytoplankton primary production and extracellular release of organic carbon. In: Hobbie, J. E. Williams, P. J. (ed.) Heterotrophic activity in the sea. NATO conference series. Plenum Press, New York and London

Sharp, J. H. (1977). Excretion of organic matter by marine phytoplankton: Do healthy cells do it? Limnol. Oceanogr. 22: 381-399

Sharp, J. H. (1984). Inputs into microbial food chains. In: Hobbie, J. E., Williams, P. J. (ed.) Heterotrophic activity in the sea. NATO conference series. Plenum Press, New York and London

Smith, W. O., Barber, R. T., Huntsman, S. A. (1977). Primary production off the coast of northwest Africa: excretion of dissolved organic matter and its heterotrophic uptake, Deep Sea Res. 24: 35-47

Smith, R. E. H., Kalff, J. (1982). Size-dependent phosphorus uptake kinetics and cell quota in phytoplankton. J. Phycol. 18: 275-284

Sommer, U. (1984). The paradox of the plankton: Fluctuations of phosphorus availability maintain diversity of phytoplankton in flow-through cultures. Limnol. Oceanogr. 29: 633-636

Storch, T. A., Saunders, G. W. (1978). Phytoplankton extracellular release and its relation to the seasonal cycle of dissolved organic carbon in a eutrophic lake. Limnol. Oceanogr. 23: 112-119

Thingstad, T. F., Pengerud, B. (1985) Fate and effect of allochthonous organic material in aquatic microbial ecosystems. An analysis based on chemostat theory. Mar. Ecol. Prog. Ser. 21: 47-62

Wiebe, W. J., Smith, D. F. (1977). Direct measurement of dissolved organic carbon release by phytoplankton and incorporation by microheterotrophs. Mar. Biol. 42: 213-233

Wolter, K. (1982). Bacterial incorporation of organic substances released by natural phytoplankton populations. Mar. Ecol. Prog. Ser. 7: 287-295 